\title{
Symbolic Efforts for Maintaining Anti-Communist Discourse on Matan Magazine
}

\author{
Radius Setiyawan ${ }^{1,2 *}$, Sri Lestari $^{1}$ \\ ${ }^{1}$ Faculty of Teacher Training and Education, University Muhammadiyah of Surabaya, Surabaya, Indonesia \\ ${ }^{2}$ Doctoral Student of Social Science; Airlangga University, Surabaya, Indonesia \\ *Corresponding author. Email: radius@um-surabaya.ac.id
}

\begin{abstract}
The discourse of communism in Indonesia is closely related to the tragedies involving the Communist Party of Indonesia (PKI). The meaning of the ideology of communism has become a symbolic fight arena. PKI as victims or as perpetrators of the massacre into a debate that continues to this day. The assumption has implications on the meaning of "communism as an ideology" in Indonesia. That to this day is still a scourge of communism for most of society is a reality. Although Suharto has fallen, the effort to preserve the anticommunist discourse into a phenomenon in Indonesia. This research study focuses on how Matan Magazine in East Java Magazine seeks to maintain the anti-communist discourse. The goal is to get the power to produce and show the view of the world's most recognized, most assumed to be true, which has legitimacysymbolic preservation efforts on the anti-communist discourse conducted with menaissance strategy, namely euphemisms, sensorics and implicature. Besides, Matan shows some old wells to preserve the discourse. Through the method of critical discourse analysis, this study showed that up to now the Muhammadiyah Islamic organization which active in reproducing the anti-communist discourse in Indonesia. It is through images and written narrative in which the magazine wanted to instill a spirit of cruelty, crime and other things are wrong on the PKI or communism. In addition to writing story and productive sites in reproducing discourse, there are still many characters that way figures have not shifted at all on the hegemony of the regime. Way of thinking that tends to stagnate on the anti-communist discourse correlated with the idea of the purification in Muhammadiyah.
\end{abstract}

Keywords: symbolic efforts, anti-communist discourse, Matan

\section{INTRODUCTION}

Although the Soeharto regime has been over, efforts to preserve the anti-communism discourse continue to be carried out by various social organizations (CSOs) in Indonesia. At the end of 2012, precisely in October Tempo, issued an exclusive coverage on the historical events of the massacre of PKI members/people considered PKI. The coverage was titled "Confessions of the 1965 hangman" [1]. A special edition containing confessions of the perpetrators of the killings (read: executioner) of the 1965 events, which presented in detail and length. The background to the emergence of this edition includes a film about the 1965 massacre entitled "The Act of Killing". The film directed by Joshua Oppenheimer was also widely reviewed in the exclusive coverage. The Tempo is in a position to try to fight anti-communist discourse by considering the PKI as a victim. The Tempo is one of the media that, through its editions has repeatedly challenged anti-communist discourse.

A few months after the exclusive coverage was published, a magazine published by the Regional Leadership of Muhammadiyah (PWM) East Java named Matan responded in the $80^{\text {th }}$ edition, March 2013 entitled "The History of
Bloody PKI," trying to counter what was written by Tempo [2]. In terms of position, Matan's writings are clearly in a position to oppose communist discourse. Based on what Setiawan wrote in Budiawan [3] in East Java, there were four different types of community trends towards the "1965 Incident" namely (a) forgive and forget, (b) forgive and not to forget, (c) do not forgive and forget, and (d) don't forgive, don't forget. Matan is in the $4^{\text {th }}$ category which is the attitude of not forgiving and not forgetting; the effort is a response to the special edition of Tempo. For Matan, the attempt to fight the discourse of communism was not the first time carried out; there were two editions which extensively discussed the dangers of communist understanding in Indonesia: 80th edition, March 2013, and $2^{\text {nd }}$ edition, September 2006. In the $2^{\text {nd }}$ edition at that time, Matan's presence coincided with September 30, and it was intended to commemorate a day called the Soeharto regime called the G30S / PKI. Both of these editions, not too many differences discussion, in a 7-year vulnerable (2-issue 80 edition) it can be understood how this magazine has a perspective on communism. Firstly, this research will focus on how Matan counter-discourse to preserve anticommunist discourse in Indonesia. The counter is carried out utilizing performing symbolic powers in the published text. Symbolic power operates in a representation space that makes symbolic resources an abstract power to create truth. Through representation, reality can be presented through the mobilization of symbol systems, both language, discourse, images, and the like [4]. 
For this reason, this research intends to examine the symbolic power carried out by conducting discourse strategies through magazines. Symbolic power is as an attempt at power over other social actors, for their existence, views, perceptions, and appreciation. The reason is the difference in world view, variations in viewpoints, and differences in values.

For Bourdieu, this form of oppression also occurs in and through cultural aspects [5]. These aspects such as language, meaning, education and symbolic system of a society. This proposition is the basis of his theory of "Symbolic Power and Symbolic Violence". It can be seen that Bourdieu was able to overcome the conflict between economics and culture.

Aunullah [6] quoting Bourdieu explains that language is one of the symbolic forms, but it is a typical symbolic form. On the one hand, like other symbolic forms, language structures social reality and is at the same time structured by it. It also functions to unite a speaker society while separating it into classes. But on the other hand, in contrast to other symbolic forms, language is a fully formal symbolic form. It still has meaning without having to refer to something tangible as a referent and thus has unlimited generative ability. One thing that also becomes Bourdieu's tendency is an approach that allows a link between theory and social practice [5][7]. Bourdieu showed this, among others, by deconstructing Saussurian and Chomskyan language theories. Both schools tend to focus on understanding language as an entity separate from social situations, and by Bourdieu deconstructed into language theory that understands language as real social practice [8]. According to Bourdieu [9], people in this era do not realize that there is a power that shackles them, even though that power is visible in plain sight. That is, power is not recognized or misrecognized by the community. This process indicates that power relations are not perceived objectively, but rather in a form that allows them to be legitimate in the eyes of their adherents.

Symbolic power also makes it possible to establish the same conception of various things such as time, place, memory, and purpose, one of which is to create a consensus of intellectual circles [9]. The symbol is the significance for Bourdieu, the main instrument in the process of social integration. As instruments of knowledge and communication, symbols also enable the creation of consensus on the meaning of the world. The agreement is also vital for the reproduction of social order.

The relevance of the theoretical framework above can be understood that Matan, as a magazine seeks to gain symbolic power over its readers in the hope of determining reality itself, and this is expected to be followed by readers as natural and given. Therefore, this power is not recognized as a form of power. It is the result of transformation from other types of identified power.

\section{RESEARCH METHODS}

The symbolic power works by the mechanism of concealing the violence it possesses, becoming something accepted as "what it really should be." To answer research questions that focus on discourse strategies, Rusdiarti [10] mentions the mechanism of symbolic violence to obtain symbolic power over discourse in two ways, namely:

a. Euphemization: usually makes symbolic violence invisible, works subtly, cannot be recognized, and is chosen "unconsciously". For example, it can be in the form of trust, obligation, loyalty, courtesy, giving, debt, reward, or mercy.

b. Sensitization: symbolic violence appears as a form of preservation of all sorts of values that are considered "moral honor". Such politeness, purity, generosity, and so on which are usually opposed to "low morale", such as violence, crime, impropriety, immorality, greed, and so on.

Besides, the text to be studied in this study also conducted a discourse strategy with the implicature model. The implicature of Kridalaksana [11] is a concept that refers to something that is applied by a speech that is not explicitly stated by the statement. The relationship between speech and what is implied is not semantic in nature, but the relation between the two is only based on the background knowledge that underlies both proportions [12]. The implication in the Matan text is something that needs to be analyzed, it is done as part of the strategy of Matan to obtain Doxa. In addition, seeing the text as a political myth constructed by the authorities becomes a relevant part of this research, in addition to seeing the use of words and sentence models, deeper looking at how historical narratives are constructed as political myths is important to do. Political phenomena are related to mythical phenomena. The relationship between kings and states, between primitive kings and modern kings is not just a logical difference, but rather provides direct guidance 'on practical events, in accordance with the actual statecraft. Taum [13] quotes Foster as saying that myths are categorized as discursive practices of intellectuals and state officials in promoting the collective identity of a nation-culture.

\section{RESULTS AND DISCUSSION}

In this section, I will carry out thematic classifications. I took that classification from several talks in the Matan text. The several classifications are as follows:

\subsection{PKI is anti-God}

Budiawan [3] explains that it began with the 1926-1927 rebellion that was crushed. In this incident the PKI started lose Muslim leaders. Such as Hajj Misbach and Hajj Datuk Batuah. Although the conflict between Muhammadiyah and Haji Misbach had occurred in the previous year, in that conflict Muhammadiyah had never considered the PKI as an anti-god party. The contradiction happened more on the perspective of fighting colonialism. PKI was more on direct action without compromise, but Muhammadiyah was more compromising. Even in those years the PKI often used Islamic terms to invite against the invaders, which in the context they named it "sabil war". Apart from the disappearance of Muslim figures in the PKI.

Another factor that made the PKI farther away from Islam was the Madiun incident, in which members of the Pesindo 
military (PKI under bow) who frantically killed their hostages were mostly Muslim. The incident also became one of the bases on the assumption that the PKI was a cruel organization especially to Muslims, and that it was continuously being reproduced. In detail I have not found any contact between Muhammadiyah and the PKI in the Madiun incident; whether the one killed was a member of Muhammadiyah, I have not seen that literature.

In Budiawan [3], quoting from Antonie C.A. Dake, it was described that the PKI had indeed carried out attacks on Muslims, but it was aimed at those who were not cooperative. In this context, they are those who have different ways of the PKI. Non-cooperative Muslims are meant here whether Muhammadiyah is indeed not explained. But if seen from the problems in previous years, this is possible because of the way Muhammadiyah is relatively different from the PKI. PKI tendency, which often attaches labels in Islamic groups to differentiate from one another may be one cause The PKI had to come face to face with various variants of Islam that year. Muhammadiyah, which in 1920 was labeled as Lamisan Islam. According to my interpretation the PKI movement tended to be hard on groups that differed from themselves, and it was very likely to be one of the reasons that kept the PKI far from some Islamic organizations. What was quite clear at the time was reactionaries with those who were revolutionaries. They call Muslims "hypocrites" against Muslims who are not in line with their ideas.

The question then is why the perspective of Muhammadiyah in Matan tends to be stagnant in understanding communism concerning atheism / anti-god. As an Islamic organization that in the context of its birth carries the vision of purification where the aim is to create a society that returns to the spirit and teachings of pure Islam and liberates Muslims from Tahayul, Bid'ah and Khurafat, Muhammadiyah in Kuntowijoyo [14] explains the ideals and reform movement spearheaded by Muhammadiyah itself actually face the context of a doublepatterned religious life; syncretic and traditional. In Kauman, K.H. Ahmad Dahlan stood in the middle of the two neighborhoods. On the one hand, he faced a syncretic Islam represented by Javanese culture, with the Kraton and the prijaji's as its supporters; and on the other side facing the traditional Islam which is spread in the pesantren. At that time a lot of public trusts approached shirk, even shirk openly. The custom of conventional Islamic societies in the form of begging for blessing on sacred tombs, magic preserving jinn, and using various types of talismans is not following the idea of purity of Islam. The belief of the Javanese people at that time was in the form of mbaurekso sacred places in the way of mountains, rivers, springs, trees, rocks, and caves. Likewise, is the belief in the gentle guardians of the village, cemeteries, homes, rice fields, and other places. Javanese people also believe in various primbon, behavior, for example, mutih (salt abstinence), and mendhem (drunken), as well as a variety of spells, petung (good-bad days), incantations, and shamanism. These are atheistic and irrational forms of anthropocentrism.

The spirit to restore the teachings of Islam as desired makes Muhammadiyah have an ideal picture. The perfect picture in question is to re-refer to the text of the holy verses and the text of the prophet Muhammad where it is considered purification because it directly refers to the text of the Koran and the Hadith. It can be imagined how Muhammadiyah's attitude towards tradition and rituals are not taught in the text of the Koran and the Hadith, let alone towards communism, which is synonymous with atheist / anti-god. The assumption that communists are atheists for Muhammadiyah becomes one of the fundamental things so long as the assumption that communism is correlated with atheists, so long as it is also Muhammadiyah cannot accept communism even though in the context of the history of the pilgrimage Misbach becomes evidence of this combination. Another thing that is a consequence of the spirit of purification is that Muhammadiyah tends to be very strict in its teachings because its interpretation of the text tends to be rigid and tends to be less courageous in critical thinking because of its determinism on the text.

\subsection{PKI is cruel}

The picture above is a construction of the discourse on how the PKI was cruelly imaged. This image is a constructive product of a regime that has been in power for a long time. Besides, Matan, in this context, is trying to preserve anticommunism discourse using the symbolic capital of Muslims to seize the symbolic power of historical meaning and interpretation. Muhammadiyah's position in this context is an organization that has played an active role in legitimizing the image of cruelty to the PKI. This was proven in the historical context that Muhammadiyah had played an active role in the massacre of PKI sympathizers and members as recorded in history, that:

a. On October 6, 1965, PP Muhammadiyah issued a statement that the Gestapu was a national disaster.

b. On October 27, 1965, PP Muhammadiyah was represented by K.H.A. Badawi and Djarnawi Hadikusuma, agreed with Maj. Gen. Soeharto, at the Kostrad building, to help each other crush the Gestapu / PKI.

The above note is undeniable that one of the triggers of this attitude is the hard friction between Masyumi and the PKI which has been going on for years and in a moment the PKI is finally in a squeezed position which results in members/ sympathizers being slaughtered, their parties disbanded and their teachings banned until now.

\subsection{The 1965-1966 events were a reaction to the PKI's actions}

In John Roosa's book titled Pretext for Mass Murder explained that to emphasize the real significance of the movement lies in the relationship of this movement with the events that followed. The September 30th Movement became a vital event only because Suharto and the surrounding officers in early October 1965 decided to make the event important: they rescued the movement, that is to say, they gave more considerable significance than was contained in this movement. They used the movement as an excuse to justify the steps they had planned against the PKI 
and President Sukarno. They exaggerated the evil nature of the campaign and the PKI to calm their minds. When they acknowledged the massacre, they said the movement was the cause of the killings as if the deaths of hundreds of thousands of people and the detention of one million more were inevitable, natural, and equitable responses. The narrative of the victim's blame which has been imprinted as a general teaching.

John Roosa's explanation that the narrative that was deliberately formed by making the momentum of 30 September 1965 as a starting point for the legitimacy of mass murder is a critical historical study amid several books that tend to consider still that it is a natural and spontaneous event [15]. As in the case of John Roosa's quote, one example of a book that still considers this is the work of Taufiq Ismail, one of Indonesia's famous poets. In his book, which contains pictures, documents, and short essays (some of which are about the problem of narcotics that are irrelevant), Ismail states that Marxism-Leninism is an evilminded ideology that inevitably leads to genocide [16]. The anti-communist massacres of 1965-66 thus is a precautionary measure: the killing was carried out to prevent a more massive massacre from being committed by the communists. The perpetrators always claimed to act in self-defense.

The logic of "Either Or" in Matan confirms that Muhammadiyah is on one side of the binary that is facing each other between the PKI and Muhammadiyah. This perspective can be related to Muhammadiyah's friction in Masyumi which is very hard. That the blind attitude towards PKI members or sympathizers might be considered as a result of the PKI's very harsh attitude towards people who differed in their views, one of which was Masyumi. Hard opinion and tend to give labels may be considered to be one of the triggers for the events of 1965-1966. However, that does not mean that it is natural if it is used as a legitimacy tool to slaughter and prohibit teaching, which in the Indonesian context must be acknowledged as well as contributing.

\subsection{Betrayers of the Nation and State}

In Matan's account, the PKI had already carried out a coup d'état three times, the first being recorded in 1926. What happened at that time was considered by many observers to be the Prambanan rebellion. In this discussion, I am not reviewing how the rebellion was organized and what factors influenced its failure, but what I thought was important was what the rebellion was for and who was coupe and betrayed by the PKI?. In the January 1926 conference it later stated the founding of the party that the PKI's revolutionary task was different from that of other communist parties; in Europe the communist party aims to achieve class prosperity and the overthrow of capitalism and in a democratic country can use parliamentary activities, Indonesia's move is outside the law and is aimed at countering foreign imperialism. For this reason, the party must overcome regional and ethnic differences, which were exploited by the realistic by political divisions and domination of the people and must unite the population in anti-Dutch national resistance: "To the outside world we protect our movements based on internationalism and are directed against capitalism and imperialism, but internally we also carry the goal of freeing the Indonesian people from the oppression and slavery of Dutch colonialism". In the description, the Prambanan incident is an attempt to fight foreign imperialism. Although in the struggle the PKI leaders experienced severe differences of opinion, the event was an attempt by the PKI to fight Dutch colonialism and how could we say it was a rebellion against the nation and state. For me, the 1926 incident became an important marker for the PKI's struggle against the Netherlands and should have gained appreciation rather than being positioned as a traitor party.

The next event was recorded in 1948. Many people call it the Madiun event. The Madiun incident is one of the events that is often and almost always related to how the PKI was imaged as a violent and cruel party. Besides, the incident was always stopped by how PKI members kill Muslims. Unraveling the events of Madiun by trying to understand what was happening at the time was something I felt was essential to do. It was done to look at history intelligently and try to avoid the bias of the Soeharto regime's rulers who had poisoned the understanding of history so full of power interests. The Madiun incident must indeed be claimed to have taken its toll. That was for me a PKI mistake, which at that time Musso was one of the actors behind the event In contrast to Tan Malaka, Musso is a Moscow fanatic about Stalin's revolution, but understanding the Madiun incident as a national uprising in my opinion is not quite right. Another discussion that needs to be parsed is whether the rebellion is an instruction from Moscow. Efimova [17] describes in detail in his book that Musso cannot be seen as a "Moscow puppet", or a tool that is blind and obedient from the hands of Moscow, the hands of Stalin and PKUS. Musso has been and remains a strict communist, who, despite his extended stay in Moscow has maintained his original view of events in Indonesia.

The next event was the 30 September 1965 incident. This event became a mandatory discussion when discussing any issues related to the PKI. Matan did not explain the relationship between the two games. The a-historical claims mentioned are also not elaborated in-depth. For me, the discussion on 30 September 1965 was complicated. The perspective by looking for who is behind the incident is a complicated part. It is due to the many historical versions of interpretations of events. Who is the mastermind and who controls the operation is a matter that continues to be debated to this day. However, the narrative of 30 September 1965 was constructed by the Suharto regime as a starting point for preserving anti-communist discourse. Besides, I believe that the massacre after the 30 September 1965 incident was a planned setting. Roosa [15] explained that for President Sukarno the action of the movement itself was called "a small ripple in the middle of a large ocean of the Indonesian National Revolution," a small event that could be resolved calmly without causing major shocks to the power structure, for The Suharto incident was a tsunami of betrayal and crime, which revealed a massive error in the Sukarno government. Suharto accused the Indonesian Communist Party (PKI) of orchestrating the movement and subsequently devised a plan to eradicate those associated with the party. The Suharto army rounded up one and a half 
million more people. All of them were accused of being involved in the movement. In one of the worst bloodbaths in the twentieth century, hundreds of thousands of people were massacred by the Army and its affiliated militias, mainly in Central Java, East Java, and Bali, from late 1965 to mid-1966. In the atmosphere of national emergency step by step Suharto seized power Sukarno and established himself as the de facto president (with authority to dismiss and appoint ministers) until March 1966. The September 30 Movement is the starting point for a series of events related to the longevity that led to mass killings and thirty-two years of dictatorship, was one of the events essential events in Indonesian history. The description of the three events above is an attempt to look at history critically amidst a worldview dominated by the Suharto regime's thinking style. By reviewing the above description, the accusation that the PKI was the mastermind behind the revolt was onesided.

\subsection{New Style Communism}

What Matan described in his text is a fear of past pressures, whether it is a perceived danger or his delusion about the risk of worrying concern. The burdens of the past that have become ingrained due to the hegemony of this regime tend to make people forget that the value of humanity is a universal value that must be shared by all those who crave peace. This phenomenon of fear creates a point of view of many people no longer use human reason in looking at events. People who try to reconcile and rehabilitate are considered as communists who want to live a communist ideology. The critical thing to pay attention to is not to let this historical burden place people who are considered communists (exs-tapol and their families) to get discriminatory treatment from the state and society. It is not freedom to believe the teachings guaranteed in our Constitution.

This is precisely the same as the attitude of Pipit Rochijat, who saw the massacre of the members of the Indonesian Farmers' Barisan (BTI) - PKI mass organizations among the peasants - in East Java, who then said sympathetically before Indonesian political exiles in Europe in the early 1970 s, but reap disappointment when the refugees responded with the question: "Are you PKI or not?". Roosa [15], through this book, wants to destroy the dichotomist way of thinking, that if not anti-PKI, it must be pro-PKI, and vice versa. As long as this way of thinking continues to be held, surely, we will continue to fail to see the 1965-1966 event as a humanitarian disaster. Our perspective will continue to be dictated by abstract ideological prejudice and narrow political calculations. Roosa added: It is also time to stop thinking of following stale stereotypes. As long as Suharto's PKI power was portrayed as an evil specter, it was impossible to understand how the party had ever become so popular, with millions of members and sympathizers. The dichotomous way of thinking above made some people believe that those who tried to look at history honestly were PKI members who tried to awaken their ideology, and this way of thinking led to the assumption that the PKI had risen again with a new style.
The assumption that the PKI was a traitor to the state and the emergence of a new style of communism was threatening if it was associated with Muhammadiyah, this organization also took part in the construction. The construction of a negative communist image is the construction of a regime massively implanted in all citizens. If linking Muhammadiyah with the Soeharto regime, history proves that Muhammadiyah, in its implementation is quite close to the regime although it must be admitted that the collapse of Suharto, Muhammadiyah through its members, also took part in the process. Geovanie in Suara Pembaruan (30/01/2008) noted the excellent relations. That was stated among other things when opening the 41st Muhammadiyah Conference (December 1985) in Surakarta [18]:

"As a person who has tasted Muhammadiyah education, I join in hoping that Muhammadiyah will grow bigger, stronger, and more charitable in broad areas."

More or less the same statement was expressed again when opening the $42^{\text {nd }}$ Conference (1990) in Yogyakarta, and more explicitly stated when opening the $43^{\text {rd }}$ Conference (1995) in Banda Aceh. At that time, the general said that he was a Muhammadiyah seedling planted for the Indonesian people. Suharto's statement in general not only boasted Muhammadiyah residents but also eased the movement of the organization that was founded by KH Ahmad Dahlan in 1912. After Suharto claimed to be the seed planted by Muhammadiyah, many of the bureaucrats claimed to be sympathizers or members of Muhammadiyah. In fact, before that, many Muhammadiyah members who were civil servants hid their true identity. I was so proud of Soeharto, one of Muhammadiyah's figures, Lukman Harun, in a discussion of the Aceh Pre-Congress stated [18]:

" if necessary Muhammadiyah proposes Pak Harto as president for life...."

The picture above can be imagined during a highly authoritarian regime, what Soeharto said in the form of praise and recognition was extraordinary energy for a community organization and almost certainly received strong support and back-up from the regime.

\subsection{Political Well Myth}

Sites (old wells and monuments) that were raised in Matan as an effort to preserve anti-communist discourse. Also, some of the opinions of figures quoted by Matan will be seen as part of a mutually influential habitus. Discussions related to old wells and PKI cannot be separated from a national event that may continue to be remembered by the public, the Lubang Buaya event. Based on the dominant assumption that Lubang Buaya is the place where generals are killed, known as heroes of the revolution. The discourse about Lubang Buaya was one of the dominant discourses in the Soeharto era. Official narratives produced by the state (state) and reproduced by society tend to spread a frightening and even creepy impression. Matan in one of his articles deliberately presented several places which according to them were the place of the slaughter of Muslims carried out by the PKI. The exciting thing is that there are similarities in the pattern of building narratives 
between old wells in East Java and Lubang Buaya in Jakarta.

The massacre was always carried out in a well and not far from where the monument was usually erected to commemorate the event in question. In discussing this theme, I will elaborate using the concept of political myth, namely the tendency of social actors to use or manipulate myths for their political interests. Political phenomena are related to mythical phenomena. The relationship between kings and states, between primitive kings and modern kings is not merely a logical difference, but also provides direct guidance - on practical events, following the actual statecraft. The pattern built on the old well's narrative is an attempt to remember an event in the hope that the generation who did not witness the incident can have a controlled interpretation by making it the basis.

Narratives about events that were produced and reproduced by or with the approval of the Suharto regime to this day are still the dominant narratives because in the Soeharto era, it was honored to be taught through the formal school curriculum of that era, socialized through official TV and film media, and preserved in public displays such as museums and monuments. The discussion regarding the old well is a narrative that is built with logic of interest and is deliberately maintained through monuments, namely that all of the wells are dumping bodies of people killed by the PKI. The construction that the PKI always killed its victims after being put in the well was a discourse that was presented.

The thing that needs attention is when crating the monument, and under what circumstances of building Monument Kragak, for example, this monument was built in the 1990s, and the distance from the 1948 Madiun event is so far away. So, it is possible that creating a narrative of an event takes place long after the event and loaded with political interests (narration after the fact). Creating a narrative of an event through a framework of thought and a public display is mythological. As a result of my search for the monuments above, almost all of the writings still use the narrative that it was a place of massacre carried out by the PKI.

\section{CONCLUSION}

Through this research, I have shown that Muhammadiyah is still an Islamic organization active in reproducing anticommunist discourse in Indonesia. It is proven by Muhammadiyah, especially in East Java through its magazine is a category of organizations whose perspective on the PKI and communist teachings has not moved much from the standpoint of the Soeharto regime. His view still tends to want to preserve anti-communist discourse seen in several symbolic power mechanisms that are practiced. In addition to discovering how the mechanism of symbolic power works, this research also tries to look critically at the construction of discourse compiled by the regime, from anti-religious discourse, traitors to the nation and other things alleged by Matan as well as the pictures that appeared in Matan magazine. Spirit magazine wanted to inculcate cruelty, crime, and other things that were bad for the PKI and communism but instead gave pictures of how the PKI was brutally killed which was substantially counterproductive to what was desired. These images were used by Matan to legitimize the cruelty of the PKI even though the picture was a cruel treatment of the PKI. The installation of these heinous images is not a technical problem, but the writer and the designer consciously understand that there has been a cruel and inhuman treatment but because of the strengthening of the regime's hegemony over them so that in this context they are not aware of borrowing images that are counterproductive. Another thing described in this study is that the narrative of an old well in East Java is a reproduction tool of anti-communist discourse. Even though the Soeharto regime no longer exists, discourse still exists, and it is useful in preserving anti-communist discourse because some of these old wells are still frequently visited by all circles in East Java. In addition to sites that are productive in reproducing discourse, there are still many figures whose way of thinking has not shifted at all over the hegemony of the regime.

Muhammadiyah's perspective which is stagnant and tends to try to preserve anti-communist discourse can be understood because there are two factors. First is the ideological factor, where the presumption of communism correlated with atheism or anti-god. As an Islamic organization that leads to the spirit of purification, it is fundamentally contrary to the teachings of Muhammadiyah. Second is the historical factor, where history proves that Masyumi, as Muhammadiyah's political container became a political opponent at which time the conflict was going very hard and toppling each other. Also, the next historical factor is the hegemony of the regime which is still durable in most members of Muhammadiyah, especially Muhammadiyah East Java through Matan.

\section{REFERENCES}

[1] Media, Media; Sedayu, Agung; Supriyanto, Agus et.al., "Dari Pengakuan Algojo 1965," Tempo, Jakarta, Oct-2012.

[2] "The History of Bloody PKI," MATAN, Surabaya, Mar-2013.

[3] Budiawan, Mematahkan Pewarisan Ingatan:

Wacana Anti-Komunis dan Politik Rekonsiliasi PascaSoeharto. Yogyakarta: Elsam, 2004.

[4] F. Fashri, Penyingkapan Kuasa Simbol; Apropriasi Reflektif Pemikiran Pierre Bourdieu. Yogjakarta: Juxtapose, 2007.

[5] C. Harker, Richard. Mahar Cheelen. Wilkes, $($ Habitus $\mathrm{x}$ Modal $)+$ Ranah $=$ Praktik. Yogjakarta: Jalasutra, 2009.

[6] I. Aunullah, "Bahasa Dan Kuasa Simbolik Dalam Pandangan Pierre Bourdieu," 2006.

[7] R. Jenkins, Pierre Bourdieu. London: Routledge, 1992. 
[8] Thompson. John B., Introduction Pierre Bourdieu Language and Symbolic Power. Cambridge: Polity Press, 1991.

[9] P. Boudieu, Language and Simbolic Power. Cambridge: Polity Press, 1991.

[10] S. R. Rusdiarti, "Bahasa, Pertarungan Simbolik dan Kekuasaan,” Yogjakarta, 2003.

[11] H. Kridalaksana, Pembentukan Kata dalam Bahasa Indonesia. Jakarta: Gramedia, 1992.

[12] M. R. Wijana, I., Dewa Putu, Analisis Wacana Pragmatik. Surakarta: Yuma Pustaka, 2009.

[13] Y. Y. Taum, "Lubang Buaya: Mitos Dan KontraMitos," 2008.

[14] Kuntowijoyo, Paradigma Islam, Intrepretasi untuk Aksi. Bandung: Mizan, 1998.

[15] J. Roosa, Dalih Pembunuhan Massal : Gerakan 30 September Dan Kudeta Suharto. Jakarta: Institut Sejarah Sosial Indonesia Dan Hasta Mitra., 2008.

[16] T. Ismail, Katastrofi Mendunia: Marxisma, Leninisma, Stalinisma, Maoisme, Narkoba (World Catastrophes: Marxism, Leninism, Stalinism, Maoiam and Narcotics). Jakarta: Yayasan Titik Infinitum, 2004.

[17] L. M. Efimova, ddari Moskow ke Madiun? StalinPKI dan Hubungan Diplomatik Uni Soviet-Indonesia, 1947-1953. Yogjakarta: Syarikat.

[18] J. Geovanie, "Hubungan Soeharto dan Muhammadiyah,” Muhammadiyah Studies, 2012. [Online]. Available: http://muhammadiyahstudies.blogspot.com/2012/12/hu bungan-soeharto-dan-muhammadiyah.html. [Accessed: 20-Nov-2011]. 